\title{
PRACTICE OF OPERATIONS IN COMPANIES OF TERESINA,
} PIAUÍ, BRAZIL

Tonny Kerley de Alencar Rodrigues Federal University of Rio de Janeiro (Coppead), Brazil

E-mail: tonny.rodrigues@coppead.ufrj.br

Átila de Melo Lira Universidade Paulista, Brazil E-mail: atilalira@hotmail.com

Irenilza de Alencar Naas Universidade Paulista, Brazil E-mail: irenilza@gmail.com

\section{ABSTRACT}

Submission: 01/04/2014

Revision: 15/04/2014

Accept: 22/04/2014

This research was structured in order to respond those research problems: The companies of the city of Teresina, Piauí, Brazil practice operations management? What tools of operations management they use? What are the tools of operations management that they need more? Therefore, this study aimed to characterize the management operations practices of Teresina undertakings, specifically, the research seeks to analyze the management practices of Teresina business operations as well as operations management tools they use in contrast to the observance of what they need most. Trying to understand these issues, we developed a quantitative survey. The research can be rated as descriptive and explanatory, applied and/or intervention. As for media, research can be classified as documentary, bibliographic and/or participant. For the better development of the study it was used a documentary approach. Regarding the sample was stratified random amount of small businesses that responded to the proposed questionnaire was used was 415 . The results showed that 
the MPEs have a number of structural features against practices and tools for managing the operations of companies Teresina, for example: complementarity and subordination relationship with large companies, low investment in technological innovation, high rate birth and death, low capital intensity, strong family presence in the composition of labor among other.

Keywords: Operations, Management, Practice

Contributors and Supporting Agencies: Capes, CNPq and Associação

Teresinense de Ensino.

\section{INTRODUCTION}

The practices of operations management tools follow a trend of increasing operational data levels competitive edge companies have lived for decades. The need to equalize the productive management may never have advanced so much in the history of the area as it has been lately with the improvement and advancement of new technologies. However, there are locations that may not yet be accompanied by such developments still act in markets with low asset specificity.

Therefore, this research appeared on the following question: what practical operations management can help small businesses in the city of Teresina, Piauí, Brazil on improving the administrative process? Was taken as the main assumption in this question that the adoption of planning and executing operations management tools can aid in reducing the lack of technical and scientific knowledge of these organizations. Therefore, this study aimed to characterize the management operations practices of Teresina undertakings, specifically, the research seeks to analyze the management practices of Teresina business operations as well as operations management tools they use in contrast to the observance of what they need most. Quantitative research, applied, descriptive was performed with the use of a survey (structured questionnaire with a representative sample of the population, $\mathrm{n}=415$ small businesses).

The focus and scope of analysis of the research focuses on management practices in small business operations Teresina because they are organizations with no study in the area so far. Moreover, these organizations have great social representativeness, since they employ the majority of the population, corresponding 
DOI: 10.14807/ijmp.v5i4.218

to most of the business organizations, but have translated their results in small efforts, since they correspond to only a small portion of gross national product.

Theoretical support of research, we chose to rescue a discussion of production and operations that would enable progress in interfaces and boundaries between the classics with their balances between production systems and discussion of classical economists administration amplifies the need for productive uses of models internally organizations. Still, we attempted to provide an overview of small Brazilian companies for this scenario is best viewed and interpreted.

\section{THEORETICAL FRAMEWORK}

\subsection{Theoretical discussion of classical economics}

The production is an administrative element that makes up most of the execution of planned strategies by firms. As it competes aspects such as the physical arrangement belonging to the "shop floor", capacity issues and decisions of what and how much to produce, inputs and their quantities to be purchased or sales forecast to assist in production decisions.

At first, to better understand how the production of an organization works, it is necessary to understand the early events of the Industrial Revolution, with their consequences in production methods. To this end, this study will show some ideas of the most important scholars and industry of that period on the forms of production and on the expectations of the employees on the production: Adam Smith, in order to streamline production, followed by Thomas Malthus, David Ricardo, Robert Owen, Frederick Taylor and Henry Poor, this specifically entered deeply into the productive aspects, formulating Scientific Management.

In the beginning of the eighteenth century was a huge change in industrial processes, the global population increased considerably, the consumer market stimulated the large-scale production and provided technological development. The workforce grew so abundant, some coming from rural and other originating from the own population growth in cities.

In this context, Britain had the technological supremacy. Due to the various colonies and the mastery of the seas, she possessed the factor necessary to give strength to the plants: the consumer market and transport. Through various 
DOI: 10.14807/ijmp.v5i4.218

inventions like the flying shuttle, hydraulic loom and the steam engine, the industry is modernized and a change was needed in production processes to streamline production (SMITH, 1976).

Serving the philosophical and theoretical bases of human behavior, business and production processes, classical liberalism caused the accumulation of capital is the term of order among merchants and factory owners (HOBSBAWM, 1981; TREVELYAN, 1967). In this scenario, by first concerns the behavior of the worker before his task and rational production.

A leading rationalizing production was Adam Smith. He pointed out that the efficient way to achieve the minimization of production time and achieve greater dexterity of the worker would be through specialization of production stages (SMITH, 1976).

During this period, the employee was subjected to inhumane conditions, with workloads that arrived 18 hours daily (MALTHUS, 1946). With regard to earnings, Ricardo (2004) expressed very well thought of the time by saying that he should be the necessary price just to ensure their survival and their class. Thus, the individual had a life at work, which was not considered their other needs.

Reviewing the literature that this study was conducted, Robert Owen is regarded as the first to make use of methods for humanizing working conditions within an industry. He was the first manufacturer to provide decent working conditions, fair wages and education for the children of their employees. Practically, it correlated better quality of life at the factory with a better performance (HUNT; SHERMAN, 1986).

In the nineteenth century, the productive efficiency continued to be "kept in check". Through specialization, division of labor was defended by John Stuart, who also advocated a salary proportional to each worker was able to produce (MILL, 1994). On the other hand, concerns about the slow production, caused by specialization, were observed by Marshall (2006), which, despite being favored the production process, believed that monotony was an evil of the first order in the division of labor.

In the late nineteenth century with the growth of American railroads, which were the greatest work in progress at the time, the project coordinator Henry Poor 
DOI: 10.14807/ijmp.v5i4.218

came to the conclusion that to achieve productive efficiency three factors were needed: the organization, communication and information. He applied motivational aspects in the work environment as wages proportionate to the performance: in order to seek satisfaction of the employee, promoted a flexible communication among various hierarchical levels and clearly communicated the information about the project objectives to the workers (POOR, 1952).

\subsection{Theoretical discussion of the classic management}

Frederick Taylor expanded all previous studies. He sought to develop the overall performance of the organization through improvements in the techniques of individual production, increasing the performance of workers and machines. Empirically applied the division of labor in simple and predefined tasks in order to try to eliminate the interference of a single worker in the entire production process. This was very important in the production process because it allowed it to be no longer necessary for industries to find workers who knew the entire production process, but only knew perform its designated task (TAYLOR, 2010).

Production is handled both in the economic and administrative sciences. The production activity is responsible for the agglutination of resources to produce goods and services. In systematic terms, any organization have a single type of transformation that is represented by the inputs, process and outputs (or inputs, processing and outputs), or any organization receives inputs, processes them and have a product or service as a result. However, despite the transformation model is the same for any company, ways of obtaining the inputs, processing and shape that occur with the output may be different and depend on the level of technological structure of the organization and line of business which operates.

The main role of the production function is to provide grants to enable companies to produce products/services demanded by consumers. Moreover, the production function also supports the business strategy, implements this strategy and drives. Support the business strategy is to develop activities necessary to provide conditions that enable the organization to achieve its strategic objectives; implement the business strategy concerns the implementation, for example, even if the strategy is brilliant, if not well executed will fail, and thrust business strategy is related to the fact of making the production of goods/services in the best way, or give competitive 
DOI: 10.14807/ijmp.v5i4.218

advantage to the strategy in the long term (MENTZER et al., 2008). The production has tools that are associated with matters relating to the planning and control, as well as the physical arrangement or layout, inventory levels, sales forecasting (which indicates the level of production to be searched) and other (MAYORGA; AHN, 2011).

\subsection{Brazilian small enterprises}

Small businesses are in accordance with Complementary Law No. 123 of December 14, 2006, the individual limited liability companies, simple partnerships, business corporations and businessman who plays professionally organized for the production of goods and services economic activity that in the case of small enterprises, or get an annual gross income equal to or less than $R \$ 360,000$ (approximately 180,000 dollars), and in the case of small business that has a gross annual income above that amount and even $R \$ 3,600,000$ (approximately $1,800,000$ dollars), and by 2011 the annual ceiling for small business was $R \$ 1,500,000$ (approximately 750,000 dollars) (BRAZIL, 2006).

In the design of Santos et al. (2011) claim that the world these companies form a productive system that allows dilution of the economy in thousands of projects. In the Brazilian case, these authors postulate that the small business play an important socioeconomic role in generating income, offering jobs and strengthen the economy.

Small enterprises form a production system worldwide that enables, on the basis of a society, the dilution of the economy in thousands of projects. Highlighting the Brazilian case, the small enterprises are important in generating income, the provision of jobs and strengthen the economy. Therefore, this segment has an important social and economic role as a center for the creation and distribution of wealth decisive in generating jobs and economic development (SANTOS et al., 2011).

According to IBGE (2011) and RAIS (2011), small enterprises correspond to most Brazilian companies and employ the majority of the population, yet they account for a small share of GDP and nearly half of them do not pass the first years of life. As pointed out by Borges et al. (2012), despite the economic representativeness of Brazilian companies, they encounter significant difficulties for the conduct of their activities and stay in the market. In this sense, one of the main 
DOI: 10.14807/ijmp.v5i4.218

factors contributing to the high mortality of these organizations is the absence of economic management tool applications.

The current Brazilian literature on the subject points out that this fact is because the managers of these organizations, largely lack the scientific knowledge about these tools (BORGES et al., 2012; KASSAI; KASSAI, 2001; RIBEIRO, 2011; SANTOS, 2012; SANTOS et al., 2011; TACHIZAWA; POZO, 2007). They manage only with the empirical knowledge, or common sense, that they call "practical". Combine this practice to the theory can be a powerful weapon for these organizations in pursuit of competitive advantage. Borges et al. (2012) show that due to the importance of local businesses, for example small enterprises, it is necessary to isolate aspects of the same failure to understand the phenomena that influence the continuity of business. Since knowledge of these causes is important to create instruments to minimize the discontinuity indices of these companies.

\section{METHODOLOGY}

In research question we chose a more positivist strand which values quantitative aspects (KUHN, 1997). As Vergara (2006), the methodology can be categorized as to the purposes and on the means. As for the purpose, the research can be descriptive and explanatory, applied and/or intervention. As for media, research can be classified as documentary, bibliographic and/or participant.

The population for this study is composed by Brazilian small enterprises are characterized by having a lower or equal to $R \$ 3,600,000$ (approximately $1,800,000$ dollars) gross annual income. They amount to about 5,786,696 business establishments, according to IBGE (2011).

Regarding the sample, it was random stratified where "n" calculated was 385 small businesses at a confidence level of $95 \%$ and a sampling error of $5 \%$. The "n" observed, for example the amount of small enterprises who answered the questionnaire proposed was 415 .

According to IBGE (2011), through its management of research, stratification of small Brazilian enterprises has the following format: $1.3 \%$ in the northern region, $14.3 \%$ in the Northeast, $55.5 \%$ in southeast, $22.4 \%$ in the south and $6.5 \%$ in the Midwest. Thus, the sample is very close to the percentages of these percentages for each region, proceeding just rounding them. 
DOI: 10.14807/ijmp.v5i4.218

To obtain these samples as close to these percentages, the researcher was counting the questionnaires answered by geopolitical region of the country. As you could be the desired percentage, going to disregard or not count most of the responses coming from that region. This procedure allowed the stratification of the sample.

To collect information regarding the diagnosis of the degree of knowledge of small entrepreneurs, a structured questionnaire using gradual tracks in identification of the respondent and the firm (such as age groups, marital status, length of business and geographic region was used business location) and a Likert type scale which is related to the operations management practice of companies in the city of Teresina, where the researcher was able to deduce the main difficulties encountered by respondents in the administrative process for these organizations and the level of skilled operations management practice of companies. The scale had the following configuration: a) Strongly agree; b) Agree in parts; c) Neither agree nor disagree; d) disagree in parts; e) Strongly disagree.

The questionnaire was filed in Google Docs (Internet tool that provides free filing of a questionnaire), and sent to the Sebraes of all states of the federation, secretaries of finance, development and farm all the states and capitals of the country, departments management, economics and accounting in various Brazilian federal universities with a disclosure requirement for small entrepreneurs. Furthermore, the researcher sent the questionnaire to your bank emails of small business owners across the country.

The pretest of the instrument was performed with some businessmen database researcher who agreed to contribute to the development and structuring of it. Data collection occurred from November 2011 to March 2012. Initially the researcher personally visited some offices Sebraes, Sesi and Sesc and some departments of farm some municipalities in the North and Northeast of Brazil to promote research and seek cooperation in sending the same link of the instrument and the awareness of entrepreneurs to reply the questionnaire.

The data relating to the questionnaire were analyzed with the help of SPSS (Statistical Package for Social Science). Through breeding techniques could be identified as the organizational structure and the type of manager that applies more 
DOI: 10.14807/ijmp.v5i4.218

or less applies operations management practice, as well as which ones that have better financial results. Also, was provided at the end of the analysis of the results, a set of operations management practices found in the literature of administrative sciences for the best management of these small enterprises.

The selection methodology and exemplification of management tools was made compatible with the defined objectives and design management as a scientific and technical process of applying scientific knowledge to seek survival and/or growth of small enterprises.

\section{RESULTS AND DISCUSSION}

The responses from 415 questionnaires with managers of Brazilian enterprises were summarized in percentage frequencies of twenty claims arising from a scale (Likert) related to practices of these managers on the operations management tools. It is noteworthy that the language used was simple due to research addressing an audience of different levels of education.

For each statement the scale contained the questionnaire, management tools for application in small business were chosen. Three factors have conditioned and guided these choices: a) the organization or require the application of these tools; b) or manager known in part or in whole the tools and; c) or manager has not yet apply the tools for not understanding the process of implementing.

Were listed the questions in the questionnaire with the operations management tools described in the literature of the area. Thus we have, for example, the existing physical space associated with the physical arrangement by product or process. That knowledge of the quantity to be sold is related to capacity expansion by means of the equilibrium point. And so on for the other affirmative and tools.

So we have that the first statement of the scale: existing today in my company is enough physical space for all activities that desire to accomplish; seeks to show that the manager believes that the layout of your company is suitable to the needs of the same. The majority of respondents $(65 \%)$ believe that companies do not have the appropriate layout because disagreed with the statement above.

The second statement: I know how much my company needs to sell at least pay the monthly bills. That is, the entrepreneur knows the balance point of your 
DOI: 10.14807/ijmp.v5i4.218

business? In the specific case of entrepreneurs who responded to the instrument of data collection, $51 \%$ do not know the balance point of sale of company products. However, this question $30 \%$ of respondents said they know clearly determine the equilibrium point. Probably only those entrepreneurs who have higher revenues must be completely agreed with the statement. If yes 3: Know the correct amount of supplies to be purchased per month by my company not to miss or leftover goods, it can be observed that $53 \%$ did not know about economic lot of shopping because they totally disagreed with this statement.

The fourth affirmative: know the right amount of feedback that my company if she does have some investment in advertising, it can be observed that $59 \%$ of respondents know technically not work and/or qualified, with forecast sales or return on investment in advertising, because disagreed with the statement. In Question 5: I know exactly towns or places that my company must sell its products for greater gains, also had a high percentage $(55 \%)$ of respondents who do not know the cost attributable to so they can determine the best markets for their products, because they also disagreed with the statement. If yes 6 : If my company want to open a new branch or a new point of sale, I will know which place greater return, $57 \%$ of small entrepreneurs disagreed with the statement, for they know not scientifically determine the appropriate location if it decides to open a new business.

So on the almost absolute majority of respondents said it disagreed with the assertions that reveal if they know management tools or not. However, in the affirmative 13: know the value (in dollars) that my company currently has on hand or in banks, there was a high percentage $(42 \%)$ of small entrepreneurs who strongly agreed with this statement compared with the percentage the other affirmative. On the other hand, the percentage of entrepreneurs who do not know the liquidity of its business is still very high (49\%) as disagreed with the statement.

\section{CONCLUSION}

That survey also identified possible, theoretical and practical, that the MSE Brazilian possess the following structural features: a) complementarity and subordination relationship with large companies; b) low investment in technological innovation; c) high rate birth and death; d) low capital intensity; e) strong family presence in the composition of labor; f) use of unskilled labor or semi qualified; g) no 
DOI: 10.14807/ijmp.v5i4.218

separation between the assets of the partners and the firm; $h$ ) barely adequate accounting records; i) centralized decision-making power; j) more difficult access to finance working capital.

The results indicate that mostly operates in the Services sector (30\%), are in the market for over 10 years (38\%), employ an average of up to 5 people $(82 \%)$ and have an average monthly turnover of up to $\$ 3,000.00$ (43\%), buying or selling of large companies $(72 \%)$, have low investment in technological innovation (59\%), have strong family presence among employees (68\%); using hand labor low-skilled (32\%); decisions are highly centralized $(79 \%)$ and machinery and equipment used in small quantity (57\%).

Finally, this research can be a starting point for the formulation of other studies that will address the small Brazilian enterprises. These studies may involve structural and fields of activity of these organizations in order to do more with sector specific analyze, or different groups of managers profiles. They may also arise studies to assess individually the impact of each practice in the management of these businesses. It is also worth mentioning that one of the shortcomings of this research was not to discuss the consistency of the different operations management practices for the different organizational structures of Brazilian enterprises. That's because not all Brazilian companies require all operations management practices presented.

\section{REFERENCES}

BORGES, G. F. et al (2012) Descontinuidade de empresas: um estudo sob a ótica dos contadores na cidade de São João Del-Rei (MG) Revista Mineira de Contabilidade, v. 13, n. 45, p. 21-28.

BRASIL (2006) Lei Complementar $n^{\circ} 123$ de 14 de dezembro de 2006. Institui o Estatuto Nacional da Microempresa e da Empresa de Pequeno Porte. Brasília: Diário Oficial da União.

HOBSBAWN, E. J. (1981) The age of capital. New York: Scribner.

HUNT, E. K.; SHERMAN, H. J. (1986) Macroeconomia. Petrópolis: Vozes.

IBGE (2011) Instituto Brasileiro de Geografia e Estatística. Pesquisa nacional por amostra de domicílios. Available: http:// www.ibge.gov.br. Accessed at: 25/09/2011.

KASSAI, J. R.; KASSAI, S. (2001) Balanço perguntado: solução para as pequenas empresas. In: SEMEAD Seminários em Administração, 9, São Paulo, Proceedings... São Paulo, FEA-USP, 2006.

KUHN, T. S. (1997) A estrutura das revoluções científicas. São Paulo: Perspectiva. 
DOI: 10.14807/ijmp.v5i4.218

MALTHUS, T. R. (1946) An essay on the principle of population as it affects the future improvement of society. New York: Doubleday and Company.

MARSHALL, A. (2006) Principles of economics. London: Macmillan.

MAYORGA, M. E.; AHN, H. S. (2011) Joint management of capacity and inventory in make-to-stock production systems with multi-class demand, European Journal of Operational Research, v. 212, n. 2, p. 312-324.

MENTZER, J. T. et al (2008) Supply chain management and its relationship to logistics, marketing, production and operations management, Journal of Business Logistics, v. 29, n. 1, p. 31-39.

MILL, J. S. (1994) Principles of political economy. London: W. J. Ashley.

OLIVEIRA, A. G. et al (2000) A utilização das informações geradas pelo sistema de informação contábil como subsídio aos processos administrativos nas pequenas empresas, Revista FAE, v. 3, n. 3, p. 01-12.

POOR, H. (1952) Men is business. New York: Harper \& Row.

RAIS (2011) Relação Anual de Informações Sociais do Ministério do Trabalho e Emprego. Available: http://www. mte.gov.br. Accessed at 25/09/2011.

RIBEIRO, D. A. S. (2011) Planejamento estratégico e o processo decisório em micro e pequenas empresas. Monografia (Graduação em Administração). Brasília: abril / UnB. Available:

http://bdm.bce.unb.br/bitstream/10483/2848/6/2011_DanielAndreSilvaRibeiro.pdf. Accessed at: 25/09/2011

RICARDO, D. (2004) On the principles of political economy and taxation.

Cambridge: Cambridge University.

SANTOS, G. M. et al (2011) Risco de sobrevivência de micro e pequenas empresas comerciais, Revista de Contabilidade e Organizações, v. 5, n. 11,p. 107-124.

SANTOS, M. B. (2012) New forms of work organization in micro and small enterprises. Available: http://mpra.ub.uni-muenchen.de/

35700/1/MPRA_paper_35700.pdf accessed at: 02/02/2012.

SMITH, A. (1976) An inquiry into the nature and causes of the wealth of nations. Oxford: Oxford University.

TACHIZAWA, T.; POZO, H. (2007) Gestão de recursos humanos em micro e pequenas empresas: um enfoque de gestão ambiental e responsabilidade social para seu crescimento, Revista da Micro e Pequena Empresa, v. 1, n. 1, p. 04-23.

TAYLOR, F. W. (2010) The principles of scientific management. New York: Harper and Brothers.

TREVELYAN, G. M. (1967) History of England. New York: Doubleday and Company.

VERGARA, S. C. (2006) Projetos e relatórios de pesquisa em administração. São Paulo: Atlas. 